\title{
The effects of balanced low calorie diet on body composition and serum leptin of obese women
}

\author{
M. Arifin Suyardi ${ }^{*}$, Win Johanes ${ }^{f}$, Indriati Pramodo Harahap ${ }^{\infty}$
}

\begin{abstract}
Abstrak
Pengaruh pemberian diet rendah kalori seimbang selama 14 hari terhadap berat badan (BB), indeks massa tubuh (IMT), tebal lipatan kulit total (TLK), massa lemak tubuh (ML), massa tubuh bebas lemak(MBL), rasio lingkar pinggang-lingkar panggul (RLpi-Lpa), dan kadar leptin serum, telah dievaluasi dengan studi eksperimental pra dan pasca pemberian diet rendah kalori seimbang 915,23 kkal dengan komposisi 55,81\% karbohidrat, 19,46\% protein dan 24,73\% lemak selama 14 hari terhadap 39 subyek perempuan obes (19-55 tahun) yang telah memenuhi criteria penerimaan dan penolakan. Data yang dikumpulkan meliputi data karakteristik demografi, data asupan energi dan makronutrien, antropometri, komposisi tubuh, dan kadar leptin serum. Terjadi penurunan berat badan secara bermakna $(p<0,05)$ dari 70,99 $\pm 8,62$ menjadi 68,81 $\pm 8,36 \mathrm{~kg}(3,07 \%)$; penurunan IMT secara bermakna $(p<0,05)$ dari 30,28 $\pm 3,11$ $\mathrm{kg} / \mathrm{m}^{2}$ menjadi 29,36 $\pm 2,94 \mathrm{~kg} / \mathrm{m}^{2}$ (3,04\%); penurunan TLK secara bermakna $(p<0,05)$ dari 99,36 $\pm 12,07 \mathrm{~mm}$ menjadi 91,29 $\pm 10,85 \mathrm{~mm}$ $(8,08 \%)$; penurunan $M L$ secara bermakna $(p<0,05)$ dari 35,41 $\pm 2,75 \%$ menjadi $33,65 \pm 2,73 \%(1,76 \%)$; peningkatan MBL secara bermakna $(p<0,05)$ dari 64,59 $\pm 2,74$ menjadi 66,35 $\pm 2,73$ (2,72\%); penurunan Lpi secara bermakna $(p<0,05)$ dari 85,87 $\pm 7,31$ menjadi 83,35 \pm 7,09 (2,93\%); penurunan Lpa secara bermakna ( $p<0,05)$ dari 107,59 $\pm 6,67$ menjadi 106,49 $\pm 6,37$ (1,02\%); penurunan Lpi-Lpa secara bermakna $(p<0,05)$ dari 0,80 $\pm 0,05$ menjadi 0,78 $\pm 0,04(2,24 \%)$; penurunan kadar leptin secara bermakna $(p<0,05)$ dari 23,31 $(12,06-71,22)$ menjadi 18,18 (7,90-65,11) (22,01\%); ditemukan korelasi positif antara kadar leptin serum dengan ML secara bermakna $(p<0,05)$ sebelum perlakuan $(r=0,47 ; p=0,003)$ dan sesudah perlakuan $(r=0,57 ; p=0,001)$. Pemberian diet rendah kalori seimbang sebesar 915,23 kkal/h selama 14 hari dapat dengan efektif menurunkan berat badan, IMT, tebal lemak bawah kulit, persentase lemak, meningkatkan persentase massa bebas lemak, menurunkan rasio lingkar pinggang, lingkar panggul dan kadar leptin serum. (Med J Indones 2005; 14: 220-4)
\end{abstract}

\begin{abstract}
The effect of balanced low-calorie diet for 14 days on body weight (BW), body mass index (BMI), total skin fold thickness (SFT), fat mass (FM), fat free mass (FFM), waist to hip ratio (WHR) and serum leptin level was evaluated by using a pre and post-experimental balanced low-calorie diet $915.23 \mathrm{kcal} /$ day with the composition of $55.81 \%$ carbohydrate, $19.46 \%$ protein and $24.73 \%$ fat for 14 days on 39 obesewomen subjects (19-55 years old) who have met the inclusion and exclusion criteria. The collected data include demographic characteristic, macronutrient and energy intake, as well as of anthropometry, FM, FFM, and serum leptin level. Body weight reduction occurs significantly $(p<0.05)$ from $70.99 \pm 8.62$ to $68.81 \pm 8.36 \mathrm{~kg}(3.07 \%)$; BMI reduction is significant $(p<0.05)$ from $30.28 \pm 3.11$ $\mathrm{kg} / \mathrm{m}^{2}$ to $29.36 \pm 2.94 \mathrm{~kg} / \mathrm{m}^{2}$ (3.04\%); Significantly reduced SFT ( $\left.p<0.05\right)$ from $99.36 \pm 12.07 \mathrm{~mm}$ to $91.29 \pm 10.85 \mathrm{~mm}(8.08 \%)$; Significantly reduced FM ( $p<0.05)$ from $35.41 \pm 2.75 \%$ to $33.65 \pm 2.73 \%$ (1.76\%); Significantly increased FFM percentage ( $p<0.05)$ from $64.59 \pm 2.74$ to $66.35 \pm 2.73(2.72 \%)$; Significantly reduced WC (waist circumference) ( $p<0.05)$ from $85.87 \pm 7.31$ to $83.35 \pm 7.09$ (2.93\%); Significantly reduced HC (hip circumference) ( $p<0.05)$ from $107.59 \pm 6.67$ to $106.49 \pm 6.37$ (1.02\%); Significantly reduced WHR ( $p<0.05)$ from $0.80 \pm 0.05$ to $0.78 \pm 0.04$ (2.24\%); Significantly reduced serum leptin ( $p<0.05)$ from 23.31 (12.06-71.22) to 18.18 (7.9065.11) (22.01\%); positive correlation is observed between serum leptin level and FM significantly $(p<0.05)$ before treatment $(r=0.47 ; p=0.003)$ and after treatment $(r=0.57 ; p=0.001)$. Balanced low-calorie diet may effectively reduce body weight, BMI, skin fold thickness, percentage of fat mass, to increase percentage of fat free mass, to reduce waist to hip ratio and serum leptin level. (Med J Indones 2005; 14: 220-4)
\end{abstract}

Keywords : Balanced low-calorie diet, obesity, leptin, body composition

\footnotetext{
* Departement of Nutrition, Faculty of Medicine, University of Indonesia, Jakarta, Indonesia

${ }^{f}$ M R Maureksa Hospital, Jakarta, Indonesia

${ }^{\infty}$ Departement of Biochemistry, Faculty of Medicine,

University of Indonesia, Jakarta, Indonesia
}

The number of obese in Indonesia particularly in cities is increasing. ${ }^{1,2}$ Obesity is a condition capable of causing various complications, thus some method of treatment is required in order to overcome the situation. ${ }^{1-5}$ Several components in homeostasis system have been recently identified which may regulate 
weight, among all is leptin hormone as key element of physiological system that maintains food absorption and weight. For the obese, level of serum leptin increases in line with the elevation of adiposity number. ${ }^{6}$ The permanently high leptin level of the obese may result in leptin resistance occurs. ${ }^{7,8}$

The decreasing of body weight (BW) besides reducing the risk of health also can reduce serum leptin concentration and improve homeostasis energy. ${ }^{9-12}$ One method for decreasing the BW is by diet therapy and a save and easy diet therapy is using balanced low calorie diet. ${ }^{13}$

The aim of this study is to determine the effect of balanced low calorie diet for 14 days on body composition and serum leptin level of obese women.

\section{METHODS}

\section{Subjects}

Subjects included 39 obese women who have been selected based on inclusion and exclusion criterion. Their average age were $40.87 \pm 8.24$ year old and body mass index $(B M I) \geq 25 \mathrm{~kg} / \mathrm{m}^{2}$. Not under diet to reducing weight, not diabetic, not hypertension, not hyperuricemie, no history of heart disease, normal function of kidney and liver, not anemia, no history of hypothyroid or hyperthyroid, not pregnant, not lactating, not taking medication to reducing weight, stimulant and depressant.

The study protocol was approved by the local ethical committee and each subject gave informed consent.

\section{Study design}

The study entailed 3 period : In pre period, information about demografi, frequency, amount and kind of several food 3 months before treatment, 24 hours activity 1 day before treatment, anthropometric measurement, and serum leptin. During treatment period, every subject received a balance low calorie diet (LCD) $1000 \mathrm{kcal} /$ day with composition carbohydrate, protein and fat were $55 \%, 20 \%$ and $25 \%$ for 14 days. Food record was used during 14 days to assess the actual intake during the treatment period. During the treatment period subjects were instructed to their usual activity pattern and to avoid caffeine, tobacco products and taken medication. In post period subject had been finished doing their diet. On the 15 day the anthropometric measurement and serum leptin level were conducted.

\section{Study measures}

Body weight was measured in hospital gown to the nearest $0.1 \mathrm{~kg}$ using a digital scale. Body height was measured to the nearest $0.1 \mathrm{~cm}$ without shoes using a microtoise. Fat mass were calculated by skinfold thickness at three sites (triceps, suprailiac and femoral) using table from Jackson and Pollock. Fat free mass were calculated by body weight and fat mass using Gibson's formulas.

After subject had 12 hours fasted overnight, venous blood samples was drawn for measurement of serum leptin which were analyzed by radioimmunoassay.

\section{Statistical analysis}

Result are expressed as means. To compare baseline values and the end values. The student $t$ test for normal variables with normal distribution was used. Otherwise the Wilcoxon test was used. The relationship between variables were studied using spearman rank correlation.

\section{RESULTS}

Mean energy intake before this study was 1815 (9502997) kcal/day with composition carbohydrate, protein and fat were $58.84 \%, 12.96 \%$ and $28.20 \%$ respectively. The average intake during the experiment was $915.23 \pm 142.35 \mathrm{kca} /$ day with nutrient composition as follows : protein $44.52 \pm 18.07 \mathrm{~g}(19.46 \%$ of total energy), carbohydrate $127.26 \pm 2.62 \mathrm{~g}$ (55.81\% of total energy) and fat $25.19 \pm 2.17 \mathrm{~g}$ ( $24.73 \%$ of total energy). Anthropometric measurement before and after the dietary treatment are shown in Table 1. 
Table 1. Mean BW, BMI, FM and FFM subject before and after the dietary treatment

$(n=39)$

\begin{tabular}{|c|c|c|c|c|}
\hline Variable & Before treatment $(n=39)$ & After treatment $(n=39)$ & $\mathrm{p}$ & Significance \\
\hline $\mathrm{BW}(\mathrm{kg})$ & $70.99 \pm 8.62$ & $68.81 \pm 8.36$ & 0.0001 & $S$ \\
\hline BMI $\left(\mathrm{kg} / \mathrm{m}^{2}\right)$ & $30.28 \pm 3.11$ & $29.36 \pm 2.94$ & 0.0001 & $S$ \\
\hline $\mathrm{FM}(\mathrm{kg})$ & $25.50 \pm 4.49$ & $23.31 \pm 4.03$ & 0.0001 & S \\
\hline $\mathrm{FM}(\%)$ & $35.41 \pm 2.75$ & $33.65 \pm 2.73$ & 0.0001 & S \\
\hline FFM (kg) & $45.53 \pm 5.13$ & $45.43 \pm 4.87$ & 0.76 & NS \\
\hline FFM $(\%)$ & $64.59 \pm 2.74$ & $66.35 \pm 2.73$ & 0.0001 & S \\
\hline WHR & $0.80 \pm 0.05$ & $0.78 \pm 0.04$ & 0.01 & $S$ \\
\hline
\end{tabular}

S: Significant, $\mathrm{p}<0.05$; NS: Not Significant $\mathrm{p} \geq 0.05$

Table 2. Energy intake before and during the study

\begin{tabular}{ccccc}
\hline & Energy $(\mathrm{kcals})$ & Protein $(\mathrm{g})$ & Fat $(\mathrm{g})$ & Carbohydrate $(\mathrm{g})$ \\
\hline Before study & 1815 & 58.80 & 51 & 267 \\
FFQ & $(950-2997)$ & $(28.5-114.0)$ & $(15.10-137.0)$ & $(132-477)$ \\
$\%$ of energy & & 12.96 & 28.20 & 58.84 \\
During study & & & $23.17 \pm 2.69$ & $118.94 \pm 3.78$ \\
$1-7^{\text {th }}$ day of the study & $850.33 \pm 144.33$ & $41.52 \pm 19.50$ & 24.51 & 55.99 \\
$\%$ of energy & & 19.53 & $27.20 \pm 1.65$ & $136.32 \pm 1.46$ \\
$8-14^{\text {th }}$ day of the study & $980.13 \pm 143.44$ & $47.55 \pm 16.62$ & 24.52 & 55.64 \\
$\%$ of energy & & 19.40 & $25.19 \pm 2.17$ & $127.62 \pm 2.62$ \\
$1-14^{\text {th }}$ day of the study & $915.23 \pm 142.35$ & $44.52 \pm 18.07$ & 24.73 & 55.81 \\
$\%$ of energy & & 19.46 & & \\
\hline
\end{tabular}

Table 3. Serum leptin before and after dietary treatment

\begin{tabular}{|c|c|c|c|c|}
\hline Variable & Before treatment $(n=39)$ & After treatment $(n=39)$ & $\mathrm{p}$ & Significance \\
\hline $\begin{array}{l}\text { Leptin Serum } \\
\quad(\mathrm{pg} / \mathrm{mL})\end{array}$ & $\begin{array}{c}23.31 \\
(12.06-71.22)\end{array}$ & $\begin{array}{c}18.18 \\
(7.90-65.11)\end{array}$ & 0.001 & $S$ \\
\hline
\end{tabular}

S: Significant, $\mathrm{p}<0.05$; NS: Not Significant $\mathrm{p} \geq 0.05$

A significant positive correlation was found between the serum leptin and percentage fat mass, both before and after treatment.

Table 4. Spearman's correlation between serum leptin and percentage fat mass before and after treatment

\begin{tabular}{ccc}
\hline & \multicolumn{2}{c}{ Percentage fat mass } \\
\cline { 2 - 3 } & $\begin{array}{c}\text { Before treatment } \\
(\mathrm{n}=39)\end{array}$ & $\begin{array}{c}\text { After treatment } \\
(\mathrm{n}=39)\end{array}$ \\
\hline $\begin{array}{c}\text { Serum leptin } \\
(\mathrm{pg} / \mathrm{mL})\end{array}$ & $\mathrm{r}=0.47$ & $\mathrm{r}=0.57$ \\
$(\mathrm{p}=0.003)$ & $(\mathrm{p}=0.001)$ \\
\hline
\end{tabular}

\section{DISCUSSION}

Defect energy intake during treatment was 929.92 $\mathrm{kcal} / \mathrm{day}$ or $13,018.88 \mathrm{kcal} / 14$ days. This defect of energy will cause the decreasing of the fat mass 1.75 $\mathrm{kg}(0.45 \mathrm{~kg}$ FM contain $3500 \mathrm{kcal}) .13 \mathrm{In}$ this present study, the mean decrease of FM is $1.79 \mathrm{~kg}$. $500 \mathrm{kcal}$ less perday cause a loss of about $0.5 \mathrm{~kg}$ a week and $1000 \mathrm{kcal}$ loss perday cause a loss about $1 \mathrm{~kg}$ a week. ${ }^{14}$ In this study the decrease of BW for 2 weeks was $2.07 \mathrm{~kg}$. 
The subject have a good compliance during the study, it was shown by the mean of energy intake which was closed to what have suggested.

The mean BMI before treatment was $30.28 \pm 3.11$ $\mathrm{kg} / \mathrm{m}^{2}$, based on WHO for Asia (2000) it was obese II. After treatment the mean BMI decreased to 29.36 $\pm 2.94 \mathrm{~kg} / \mathrm{m}^{2}$, based on WHO for Asia (2000) it was obese I.

The mean WHR before treatment was $0.80 \pm 0.05$, based on Cotton (1996) it was medium risk for health, after treatment the mean WHR decreased to $0.78 \pm$ 0.04, based on Cotton (1996) it was low risk for health.

The mean of serum leptin before treatment was 23.31 $(12.06-71.22) \mathrm{pg} / \mathrm{mL}$, after treatment was 18.18 $(7.90-65.11) \mathrm{pg} / \mathrm{mL}$, statistically significant reduced $5.13 \mathrm{pg} / \mathrm{mL}(22.01 \%)$.

Energy restriction and the effect of decreasing the body weight can reduce the serum leptin of the obese people, leptin concentration can also decrease as a reaction of the short term fasting ( 24 hours) to human and animal. ${ }^{10,15}$

There are some influences from quantity and composition of macronutrient to the serum leptin in diet process when decreasing the body weight, out of decreasing the fat mass. Serum leptin can decrease during 24 hours fasting and can increase after 4-5 hours after meal. Fasting cannot influences the serum leptin if the condition is in euglucemia, because glucose is the nutrition signal for adiposite to synthesis leptin. Other fact proves that the serum leptin is on $02.00 \mathrm{am}$. The peak of the serum leptin can be shifted 12 hours to the people who work at night. Change of the intake time (6.5 hours) can change the peak time of serum leptin within 5-7 hours.

Macronutrient composition in diet can also influences the concentration of the serum leptin, low carbohydrate diet will give lower glucose and insulin response than the high carbohydrate diet. ${ }^{15,17}$

Table 4 shows a statiscally significant of positive correlation between serum leptin and fat mass, before $(\mathrm{r}=0.47)$ and after treatment $(\mathrm{r}=0.57)$. It's because the serum leptin is an adiposite hormone.

\section{CONCLUSION}

Balanced low calorie diet was had shown to reduce BW, BMI, percentage of fat mass, to increase percentage of fat free mass, to reduce waist to hip ratio, serum leptin significantly, and positive correlation was obtained as well through this study between serum leptin level and body fat mass.

\section{REFERENCES}

1. Suyono S. Penatalaksanaan obesitas secara rasional: farmakologik dan non farmakologik. Simposium Obesitas, apakah suatu penyakit. Jakarta, 2001.

2. Oemardi M. Aspek biomolekuler obesitas. Simposium Obesitas, apakah suatu penyakit. Jakarta, 2001.

3. Soewondo P. Obesitas sebagai factor risiko penyakit jantung koroner. Simposium Obesitas, apakah suatu penyakit. Jakarta, 2001.

4. Seidell JC. The epidemiology of obesity. In: International textbook of obesity (Bjorntorp P. ed.) 23-9 John Wiley and Sons, UK, 2001

5. Lean M. Introduction to the topic. In: Obesity the benefits of moderate weight loss (Susan Hames ed.). 3-8. Colwood House Medical Publication, UK, 1997.

6. Friedman J. Obesity in the new millennium. Nature Insight Obesity. 2000; 404:624-32.

7. Chu NF, Stampfer MJ, Spiegelman D et al. Dietary and lifestyle factors in relation to plasma leptin concentrations among normal weight and overweight men. Int $\mathbf{J}$ Obes 2001; 25:106-14.

8. Considine RV, Sinha MK, Heiman ML et al. Serum immunoreactive leptin concentrations in normal weight and obese human. N Engl J Med 1996; 334:292-5.

9. Wisse BE, Camfield LA, Marliss EB et al. Effect of prolonged moderate and severe energy restriction and refeeding on plasma leptin concentrations in obese women. Am J Clin Nutr 1999; 70:321-30.

10. Racette SB, Kohrt WM, Landt M et al. Response of serum leptin concentrations to $7 \mathrm{~d}$ of energy restriction in centrally obese African Americans with impaired of diabetic glucose tolerance. Am J Clin Nutr1997; 66:33-7.

11. Grinspoon SK, Askari H, Landt ML et al. Effects of fasting and glucose infusion on basal and avernight leptin concentrations in normal weight women. Am J Clin Nutr 1997; 66:1352-6

12. Rosenbaum M, Nicolson M, Hirsch J et al. (1997). Effects of weight change on plasma leptin concentration and energy expenditure. J Clin Endocrinol Metab 1997; 82:3647-54.

13. Dwyer JT, Lu D. Popular diets for weight loss from nutritionally hazardous to healthful dalam Obesity theory and therapy (Stunkard AJ ed.) $2^{\text {nd }}$ ed. pp.231-52. Raven press, Ltd, New York, 1993.

14. Bray GA. Who are the obese? Body composition and prevalence. In: Contemporary diagnosis and management of obesity. pp.9-23. Handbook in health care co. Pennsylvania, 1998. 
15. Considine RV. Regulation of leptin production. Reviews in endocrine \& metabolic disorders 2001; 2:357-63.

16. Bennet FI, Anderson NMF, Wilks R et al. Leptin concentrations in women is influenced by regional distribution of adipose tissue. Am J Clin Nutr 1997; 66:1340-4.
17. Miyawaki T, Masuzaki H, Ogawa Y. Clinical implications of leptin and its potential humoral regulators in long-term low-calorie diet therapy for obese humans. Eur J Clin Nutr 2002; 56:593-600. 